\title{
РАДІОХІРУРГІЧНИЙ МЕТОД ЛІКУВАННЯ ЕПІТЕЛІАЛЬНИХ ПУХЛИН ШКІРИ
}

\author{
О. О. Ошивалова ${ }^{1,2}$, С. І. Шармазан ${ }^{1}$
}

${ }^{1}$ Науково-практичний центр профілактичної та клінічної медицини Державного управління справами, м. Київ, ${ }^{2}$ Національна медична академія післядипломної освіти імені П. Л. Шупика, м. Київ

\section{RADIOSURGICAL METHOD OF TREATMENT OF CUTANEOUS EPITHELIAL TUMORS}

\author{
O. O. Oshivalova ${ }^{1,2}$, S. I. Sharmazan ${ }^{1}$ \\ ${ }^{1}$ Scientific Practical Centre of Prophilactic and Clinical Medicine, Kyiv, \\ ${ }^{2}$ Shupyk National Medical Academy of Postgraduate Education, Kyiv
}

\begin{abstract}
Рефрерат
Вступ. Проблема раку шкіри актуальна в Україні, необхідне поліпшення ефективності лікування.

Мета дослідження: вивчення ефективності радіохірургічного методу лікування епітеліальних пухлин шкіри.

Матеріали і методи. Проаналізовані персоніфіковані дані 37 хворих, яких лікували з приводу плоскоклітинного раку шкіри (cSCC), 67 - актинічного кератозу (АK), 25 - інтраепідермальної карциноми шкіри (SCCis). Порівнювали ефективність методів лікування епітеліальних пухлин шкіри з використанням дерматологічного індексу якості життя.

Результати. Представлений аналіз спостережень за статтю і віком хворих, локалізацією і розмірами ураження шкіри, використаною медичною технологією.

Висновок. Вибір радіохірургічної медичної технології лікування епітеліальних пухлин шкіри обґрунтований, що підтверджує клінічна й косметична ефрективність.

Ключові слова: плоскоклітинний рак шкіри; актинічний кератоз; інтраепідермальна карцинома шкіри; радіохірургічний метод.

Abstract

Introduction. The cutaneous cancer problem in Ukraine is an actual one, improvement of the treatment efficacy is needed.

Objective. Studying of efficacy for radiosurgical method of treatment of epithelial cutaneous tumors.

Materials and methods. Personified data of 37 patients, who were treated for a squamous-cell cutaneous carcinoma, 67 - actinic keratosis, 25 - intraepidermal cutaneous cancer were analyzed. Efficacy of the treatment methods for epithelial cutaneous tumors, using dermatological index of quality of life, was compared.

Results. The analysis was presented for observation in accordance to the patients' gender and the age factor, the cutaneous affections - to their localization and dimensions, and medical technology applied.

Conclusion. The choice of radiosurgical medical technology of the epithelial cutaneous tumors treatment is a substantiated one, what is proved by their clinical and cosmetic efficacy.

Keywords: squamous-cell cutaneous cancer; actinic keratosis; intraepidermal cutaneous cancer; radiosurgical method.
\end{abstract}

За даними статистики, щороку частота немеланомного раку шкіри (НМРШ) серед населення Европи, США, Канади й Австралії збільшується на 3 - 8\%. Проте, точна кількість хворих невідома, оскільки у більшості країн НМРШ не відображені в канцер-реєстрах $[1,2]$. За уточненими даними Національного канцерреєстру України, у 2014 - 2015 рр. в структурі захворюваності населення від 10\% - у чоловіків до 12,8\% - у жінок становив рак шкіри саме епітеліального походження, 3 них друге місце посідав плоскоклітинний рак шкіри [3].

Плоскоклітинний рак шкіри (cutaneous squamous cell carcinoma - cSCC), частота якого становить від 5 до 15\%, виникає на ділянках шкіри, що протягом тривалого часу перебували під впливом надмірного сонячного опромінення [4]. Серед захворювань, що підвищують ри- зик виникнення сSCC, виділяють АК та інтраепідермальну карциноmy (squamous cell carcinoma in situ SCCis) $[5,6]$.

Дані епідеміологічних досліджень свідчать про високу частоту виникнення АК в популяціях за I - III фототипу шкіри. В країнах Европи цей показник становив у середньому $15 \%$ - у чоловіків, 6\% - у жінок; у Великій Британії - у 34\% чоловіків і 18\% - жінок віком старше 70 років [7]. Найбільші показники відзначені в країнах, територіально близьких до екватора, з великою кількістю світлошкірого населення, зокрема, в Австралії, де АК виявлений більш ніж у 55\% чоловіків віком від 30 до 70 років і 37\% жінок такого самого віку [8].

За даними зарубіжних дослідників, ризик прогресування АК до інвазивного плоскоклітинного раку становить від 0,025 до 16\% на рік. У типового пацієнта виявляють від 6 до
8 вогнищ ураження, тому у пацієнтів 3 кількома АК щороку ризик виникнення сSCC становить від 0,15 до $80 \%$ [7].

SCCis, по суті, еквівалентно використовують 3 терміном «неінвазивна форма плоскоклітинного раку шкіри». Ризик прогресування SCCis в інвазивну форму плоскоклітинного раку оцінюють від 3 до 5\% [6]. За даними British Association of Dermatologist (2014), щороку peєструють 15 спостережень SCCis на 100000 населення. Пік захворюваності спостерігають на сьомому десятилітті життя пацієнтів, у більшості досліджень відзначене невелике перевищення захворюваності жінок [9]. Захворювання локалізується в основному на відкритих ділянках шкіри з переважанням на шкірі голови і шиї (29 - 54\%) [6]

Незважаючи на низьку захворюваність і відносно невисокий рівень 
злоякісного прогресування, SCCis становить значний інтерес, оскільки є можливим індикатором канцерогенезу, особливо НМРШ [6].

У теперішній час існують різні підходи до лікування АК, SCCis i cSCC, в тому числі деструктивні методики (хірургічний метод, лазерна абляція, кюретаж, кріодеструкція) [10 - 13]. До деструктивних методів лікування належить і радіохірургічний метод, що зумовлює теплове руйнування тканини-мішені за допомогою електричного струму з частотою 0,5 МГц, $з$ мінімальним тепловим ушкодженням навколишніх тканин, забезпечуючи хороші естетичні результати [14].

Останнім часом використовують фотодинамічну терапію та локальне введення цитостатичних препаратів, наприклад, іміквімоду. Ці неінвазивні методи вважають альтернативою при лікуванні ураження великої площі шкіри або з косметичних міркувань. Проте, деструктивні методи лікування є ефективним й економічним стандартом лікування епітеліальних пухлин шкіри $[12,13]$.

Метою дослідження було вивчення ефективності радіохірургічного методу лікування епітеліальних пухлин шкіри.

\section{МАТЕРІАЛИ I МЕТОДИ ДОСЛІДЖЕННЯ}

Для досягнення поставленої мети використані персоніфіковані дані хворих, які з приводу AК, SCCis i CSCC перебували під динамічним спостереженням лікарів Центру, а також дані опитування щодо якості життя хворих на момент встановлення діагнозу, через 3 міс і 1 рік після лікування 3 використанням дерматологічного індексу якості життя (Dermatology Life Quality Index DLQI). DLQI - це затверджений опитувальник для загальної дерматологічної оцінки якості життя дорослих. Він включає 10 запитань, кожне оцінене від 0 до 3 балів, максимум 30 балів. Чим вище показник, тим більш виражене погіршення якості життя. Результати інтерпретовані, дані такі рекомендації: 0 - 1 бал немає впливу захворювання на якість життя пацієнта; 2 - 5 балів - невеликий вплив; 6 - 10 балів - помірний вплив; 11 20 балів - значний вплив; 21 - 30 балів - надзвичайний вплив захворю- вання на якість життя пацієнта [15]. Ураження шкіри підтверджене даними гістологічного дослідження в усіх пацієнтів. Статистична обробка результатів проведена з використанням програми Statistica 7.0.

\section{РЕЗУЛЬТАТИ}

Під спостереженням у 2015 2016 рр. перебували 37 хворих 3 приводу cSCC, 67 - АК, 25 - SCCis. Характеристика хворих включала стать, середній вік, локалізацію, розміри ураження шкіри.

337 хворих, яких лікували з приводу cSCC, було 26 (70,3\%) чоловіків, 11 (29,7\%) жінок, віком у середньому $(77,1 \pm 4,8)$ року, в тому числі чоловіків - $(75,7 \pm 4,4)$ року, жінок - $(81,5 \pm 6,3)$ року. сSCC локалізувався переважно на шкірі голови та шиї - у 27 (73\%) хворих, обличчя - у 16 $(43,2 \%)$, волосистої частини голови - у 5 (13,5\%), вушних раковин - у 6 (16,3\%); тулуба - у 9 (24,3\%), спини в 1 ; верхньої кінцівки - у 2,7\%. У більшості хворих діаметр пухлини від 0,5 до 1 см, в тому числі у 38,5\% чоловіків і 45,5\% жінок, від 1 до 1,5 cм відповідно у 34,6 і 45,5\%.

367 хворих, обстежених з приводу АК, було 43 (64,2\%) чоловіка і $24(35,8 \%)$ жінки, віком у середньому $(74,4 \pm 6,2)$ року, в тому числі $(74,8 \pm 6,3)$ року - чоловіків та $(73,7$ $\pm 6,1)$ року - жінок. Ураження локалізувалось переважно на шкірі голови та шиї - у 47 (70,1\%) хворих, обличчя - у 31 (46,3\%), волосистої частини голови - у 9 (13,4\%), вушних раковин - у 7 (10,4\%); верхніх кінцівок - в 11 (16,4\%), плеча - у 4 (6,0\%), передпліччя - у 4 (6,0\%), кисті - у 3 (4,4\%); тулуба - у 7 (10,4\%), спини у 4 (6,0\%), грудей - у 3 (4,4\%); нижніх кінцівок - у 2 (3,1\%). У більшості хворих діаметр пухлини від 0,5 до 1 см - відповідно 67,4\% чоловіків і 70,8\% жінок.

325 хворих, обстежених 3 приводу SCCis, чоловіків було 14 (56\%), жінок - 11 (44\%), віком у середньому $(74,4 \pm 7,8)$ року, в тому числі чоловіків - (74,4 $\pm 6,8)$ року, жінок $(73,8 \pm 8,9)$ року. Переважно SCCis локалізувався на шкірі голови та шиї - у 13 (52\%) хворих, обличчя - у 12 (48\%), волосистої частини голови в 1 (4\%); верхніх кінцівок - у 5 (20\%), плеча - у 3 (12\%), кисті - у 2 (8\%); тулуба - у 6 (24\%), спини - у 4 (16\%), грудей - у 2 (8\%); нижніх кінцівок в 1 (4\%). У більшості хворих діаметр пухлини від 0,5 до 1 см - відповідно у 71,4\% чоловіків і 81,8\% жінок.

3 запропонованих методів лікування переважали хірургічні медичні технології - у 97,7\% чоловіків 3 приводу АК, у 45,4\% жінок - 3 приводу SCCis. Так, радіохірургічне лікування запропоноване за наявності АК за будь-якого діаметра пухлини, SCCis - за діаметра пухлини до 1,5 cм, cSCC - за діаметра пухлини до 1 см. Хірургічне лікування запропоноване хворим з приводу SCCis - за діаметра пухлини понад 1,5 cм, cSCC за діаметра пухлини понад 1 см. Інші медичні технології представлені кріотерапією (у 2 хворих з приводу АК, 1 - SCCis), лазерною абляцією (по 1 спостереженню 3 приводу SCCis i cSCC), поєднанням кріометоду з брахітерапією (в 1 хворого 3 приводу cSCC).

Клінічну ефективність запропонованої медичної технології оцінювали 3 огляду на наявність ускладнень під час лікування та виникнення рецидивів захворювання. При застосуванні радіохірургічної та хірургічної технології ускладнень (біль, набряк, почервоніння, вторинне інфікування) не було, що свідчило про достатню увагу медичного персоналу до навчання пацієнта правил догляду після операції, доступність цих правил, дотримання пацієнтом рекомендацій, ефективним динамічним супроводом хворого під час та після лікування.

В 1 (2,7\%) хворої, у якої з приводу сSCC застосований кріометод в поєднанні з брахітерапією, виникло ускладнення у вигляді утворення гіпертрофічного рубця з запаленням. Ще в 1 (4\%) хворої виник рецидив SCCis після кріотерапії первинної пухлини. У 65 (97,0\%) хворих, яких лікували з приводу АК, 23 (92\%) - SCCis та 35 (94,6\%) - сSCC, після радіохірургічного та хірургічного лікування, рецидиву захворювання або косметичних ускладнень не було протягом 2 років спостереження, що свідчило про достатню ефективність запропонованої терапії.

У хворих, яким з приводу SCCis запропоновано радіохірургічну методику лікування, на момент встановлення діагнозу показник DLQI становив у середньому $(4,8 \pm 0,3)$ бала, 
Показники DLQI у хворих, яких лікували з приводу AK, SCCis, cSCC

\begin{tabular}{|c|c|c|c|c|c|}
\hline \multirow{2}{*}{ Діагноз } & \multirow{2}{*}{$\begin{array}{c}\text { Кількість } \\
\text { хворих }\end{array}$} & \multirow{2}{*}{ Лікування } & \multicolumn{3}{|c|}{ Показник DLQI, балів ( $\overline{\mathrm{x}} \pm \mathrm{m})$} \\
\hline & & & до лікування & через 3 міс & $\mathrm{p}$ \\
\hline \multirow{2}{*}{$\mathrm{AK}$} & \multirow{2}{*}{65} & Радіохірургічне (n=63) & $8,4 \pm 0,4$ & $0,06 \pm 0,01$ & 0,001 \\
\hline & & Хірургічне $(n=2)$ & $8,3 \pm 0,2$ & $0,05 \pm 0,03$ & 0,001 \\
\hline \multirow{2}{*}{ SCCis } & \multirow{2}{*}{23} & Радіохірургічне (n=16) & $4,8 \pm 0,3$ & $0,12 \pm 0,03$ & 0,023 \\
\hline & & Хірургічне $(n=7)$ & $4,7 \pm 0,4$ & $0,13 \pm 0,03$ & 0,034 \\
\hline \multirow{2}{*}{$\operatorname{cSCC}$} & \multirow{2}{*}{35} & Радіохірургічне (n=25) & $8,4 \pm 0,2$ & $0,75 \pm 0,04$ & 0,021 \\
\hline & & Хірургічне (n=10) & $8,2 \pm 0,3$ & $0,72 \pm 0,03$ & 0,022 \\
\hline
\end{tabular}

що відповідало незначному впливу на якість життя хворих; за наявності сSCС та АК - відповідно $(8,4 \pm 0,4)$ i $(8,4 \pm 0,2)$ бала, що відповідало помірному впливу на якість життя (див. таблицю).

Через 3 міс після лікування вивчали короткострокове задоволення пацієнтів застосованою медичною технологією. Так, середній показник DLQI у хворих, яким запропоноване радіохірургічне лікування з приводу AK, SCCis та cSCC, достовірно (р $<0,05)$ відрізнявся від такого до лікування, що свідчило про задоволення пацієнтів результатом лікування.

Середні показники DLQI до і через 3 міс лікування у хворих, яким запропонований хірургічний метод, достовірно не різнились від таких при використанні радіохірургічного методу.

Через 1 рік після лікування показник DLQI становив 0 балів в усіх па- цієнтів після хірургічного та радіохірургічного лікування, що свідчило про високе довгострокове задоволення пацієнтів.

\section{ОБГОВОРЕННЯ}

Відсутність ускладнень під час лікування свідчила про партнерські відносини «пацієнт-лікар», прихильність пацієнтів до призначень лікаря, ефективний обернений зв'язок, основані на достатньому поясненні лікарем механізму дії медичної технології, очікуваного результату лікування і медичного супроводу.

Короткострокове задоволення, імовірно, пов'язане з партнерськими відносинами «пацієнт-лікар», довгострокове - $є$ відображенням результативності медичної технології.

Відсутність ускладнень під час лікування та рецидивів захворювання протягом 2 років спостереження, високе короткострокове і дов- гострокове задоволення пацієнтів є свідченням результативності радіохірургічної медичної технології лікування AK, SCCis i cSCC.

\section{ВИсНОВки}

1. Захворюваність на передрак та рак шкіри населення України зумовлює актуальність вивчення існуючих стратегій медичної допомоги пацієнтам.

2. Представлений матеріал висвітлює результати застосування радіохірургічної медичної технології порівняно $з$ хірургічним методом лікування епітеліальних пухлин шкіри.

3. Результати проведеного дослідження свідчать про обгрунтований вибір радіохірургічної медичної технології в лікуванні епітеліальних пухлин шкіри, тому підтверджують клінічну та косметичну ефективність запропонованої терапіі.

\section{REFERENCES}

1. Karia PS, Han J, Schmults CD. Cutaneous squamous cell carcinoma: estimated incidence of disease, nodal metastasis, and deaths from disease in the United States 2012. J Am Acad Dermatol. 2013;68:957-66.

2. Trakatelli M, Ulrich C, del Marmol V, Euvrard S, Stockfleth E, Abeni D. Epidemiology of nonmelanoma skin cancer (NMSC) in Europe: accurate and comparable data are needed for effective public health monitoring and interventions. Br J Dermatol. 2007;156(3):1-7.

3. National Cancer Registry of Ukraine: short description of the database as of January. 2016; http://www.ncru.inf.ua/publications/index. htm.

4. Burton KA, Ashack KA, Khachemoune A. Cutaneous squamous cell carcinoma: A review of high-risk and metastatic disease. Am J Clin Dermatol. 2016;17(5):491-508.

5. Berhane T, Halliday GM, Cooke B, Barnetson RS. Inflammation is associated with progression of actinic keratoses to squamous cell carcinomas in humans. Br J Dermatol. 2002;146:810-15.

6. Morton CA, Birnie AJ, Eedy D. J. British Association of Dermatologists' guidelines for the management of squamous cell carcinoma in situ (Bowen's disease) 2014. Ibid. 2014;170(2):245-60.

7. McBride P, Neale R, Pandeya N, Green A. Sun-related factors, betapapillomavirus, and actinic keratoses: a prospective study. Arch Dermatol. 2007;143(7):862-68.
8. Frost C, Williams G, Green A. High incidence and regression rates of solar keratoses in a queensland community. J Invest Dermatol. 2000;(115):273-7.

9. Westers-Attema F, Van Den Heijkant BG, Lohman PM, Nelemans PJ, Winnepenninckx V, Kelleners-Smeets NW, et al. Bowen's disease: a six-year retrospective study of treatment with emphasis on resection margins. Acta Dermato-Venerologica. 2014;(94):431-5.

10. Feldman SR, Fleischer AB, Williford PM, Jorizzo JL. Destructive procedures are the standard of care for treatment of actinic keratoses. J Am Acad Dermatol. 1999;40:43-7.

11. Chaqas FS, Silva B de S. Mohs micrographic surgery: a study of 83 cases. An Bras Dermatol. 2012;87(2):228-34.

12. Warino L, Tusa M, Camacho F, Teuschler H, Fleischer AB Jr, Feldman SR. Frequency and cost of actinic keratosis treatment. Dermatol Surg. 2006;32(8):1045-9.

13. Ulrich M, Maltusch A, Röwert-Huber J, González S, Sterry W, Stockfleth E, et al. Actinic keratoses: non-invasive diagnosis for field cancerisation. Br J Dermatol. 2007;156 (3):13-7.

14. Mutalik S. Standard guidelines for electrosurgery with radiofrequency current. In J Derm Vener Leprol. 2009;(75):83-9.

15. Ceilley RI, Jorizzo JL.Current issues in the management of actinic keratosis. J Am Acad Dermatol. 2013;68(1):28-38. 